IZA DP No. 7137

Getting Disabled Workers Back to Work:

How Important Are Economic Incentives?

Elisabeth Fevang

Inés Hardoy

Knut Røed

January 2013 


\title{
Getting Disabled Workers Back to Work: How Important Are Economic Incentives?
}

\author{
Elisabeth Fevang \\ The Ragnar Frisch Centre for Economic Research \\ Inés Hardoy \\ Institute for Social Research \\ Knut Røed \\ The Ragnar Frisch Centre for Economic Research \\ and IZA
}

Discussion Paper No. 7137

January 2013

\author{
IZA \\ P.O. Box 7240 \\ 53072 Bonn \\ Germany \\ Phone: +49-228-3894-0 \\ Fax: +49-228-3894-180 \\ E-mail: iza@iza.org
}

\begin{abstract}
Any opinions expressed here are those of the author(s) and not those of IZA. Research published in this series may include views on policy, but the institute itself takes no institutional policy positions. The IZA research network is committed to the IZA Guiding Principles of Research Integrity.

The Institute for the Study of Labor (IZA) in Bonn is a local and virtual international research center and a place of communication between science, politics and business. IZA is an independent nonprofit organization supported by Deutsche Post Foundation. The center is associated with the University of Bonn and offers a stimulating research environment through its international network, workshops and conferences, data service, project support, research visits and doctoral program. IZA engages in (i) original and internationally competitive research in all fields of labor economics, (ii) development of policy concepts, and (iii) dissemination of research results and concepts to the interested public.
\end{abstract}

IZA Discussion Papers often represent preliminary work and are circulated to encourage discussion. Citation of such a paper should account for its provisional character. A revised version may be available directly from the author. 


\section{ABSTRACT}

\section{Getting Disabled Workers Back to Work: How Important Are Economic Incentives?*}

We investigate the impacts of economic incentives on the duration and outcome of temporary disability insurance (TDI) spells. The analysis is based on a large quasi-experiment in Norway, with a complete overhaul of the TDI benefit system. Our findings show that the labor supply of TDI claimants responds to both the benefit-level and to the level of local labor demand. The estimated elasticity of the employment hazard with respect to the benefit-level is -0.3 . We also find that the level of TDI benefits significantly affects the transition rate to alternative social insurance programs such as permanent disability and unemployment.

JEL Classification: H55, I38, J22

Keywords: temporary disability, rehabilitation, hazard rate models, labor supply

Corresponding author:

Knut Røed

The Ragnar Frisch Centre for Economic Research

Gaustadalléen 21

0349 Oslo

Norway

E-mail: knut.roed@frisch.uio.no

\footnotetext{
" This paper is part of the project "Activation and Social Insurance", financed by the Norwegian Research Council (grant \#185201). The paper is also part of the research activities of the centre of Equality, Social Organization, and Performance, University of Oslo. Data received from Statistics Norway has been essential for the project and for the paper. Thanks to Bernt Bratsberg and to participants at the 2013 annual meeting of the Norwegian Association of Economists for valuable comments.
} 


\section{Introduction}

Over the last decades, many countries have experienced a significant growth in the caseloads of disability insurance programs; see, e.g., Autor and Duggan (2003), Duggan and Imberman (2006), Bratsberg et al. (2010), and Burkhauser and Daly (2011). Although "the disability problem" has been overshadowed by the soaring unemployment rates after the onset of the Great Recession, it represents one of the major challenges for industrialized economies over the long term. Recent empirical evidence also indicates that there is an important element of substitutability between unemployment and disability insurances, and that the root cause of disability program entry often is the absence of acceptable employment opportunities; see, e.g., Black et al. (2002), Autor and Duggan (2003), Rege et al. (2009), and Bratsberg et al. (2010). This suggests that when the Great Recession comes to its close, we may find that it has left behind a challenging, and potentially longlasting, disability problem; see Røed (2012).

Economists have long been concerned about the apparent lack of appropriate work incentives in disability insurance programs. The increasing awareness of the overlap between unemployment and health problems, and the accumulating evidence that many disability insurance claimants are in possession of a considerable remaining work capacity (French and Song, 2009; Maestas et al., 2011; Von Wachter et al., 2011; Kostøl and Mogstad, 2012), make this issue even more acute. Yet, the empirical evidence on the impacts of economic incentives embedded in disability insurance programs is sparse and fragmented. While there have been numerous investigations into the issue of how unemployment insurance (UI) affects unemployment duration, see, e.g., Fredriksson and Holmlund (2006), and Card et al. (2007), or Røed et al. (2008) for recent overviews, there have, to our knowledge, been very few investigations into the impacts of economic incentives on the duration and outcomes of disability insurance spells. As pointed out by Autor et al. (2012) in relation to the missing evidence on possible disincentives effects in the U.S. Social Security Disability Insurance Program (SSDI), a major reason for this is the lack of exogenous variation in benefit levels. In addition, the large differences between countries in the way they have designed (and labeled) their (often plentiful) disa- 
bility insurance programs (OECD, 2010) have made research findings less "transferable" across countries.

Yet, there are some pieces of evidence indicating that labor supply behavior of disability insurance claimants do respond to economic incentives. In particular, studies based on the U.S. workers' compensation program for work-related injuries - exploiting the variation in coverage plans across workplaces and workers - find that insurance spells become longer as the level of compensation increases; see, e.g., Butler and Worrall (1985), Meyer et al. (1995), and Krueger and Meyer (2002). There is also a more recent piece of evidence based on an evaluation of the private Long Term Disability program, also indicating that spell duration depends positively on the benefit level, although large statistical uncertainty makes it difficult to draw clear conclusions in this case (Autor et. al., 2012). Kostøl and Mogstad (2012) show that when a Norwegian permanent disability insurance program was reformed such that claimants were allowed to retain more of their benefits when incomes were topped up with labor earnings, many recipients started to work (more). Finally, evidence based on reforms of the Swedish sick-pay system indicates that the level of absenteeism depends positively on the compensation level (Johansson and Palme, 2002; Henreksson and Persson, 2004).

Based on administrative register data from Norway, the present paper offers new evidence on the impacts of financial incentives on the duration and outcome of disability insurance spells. The program we examine is a temporary disability insurance (TDI) program; it covers workers who have exhausted their one-year sick-pay entitlements with the employer (or who were not entitled to sick-pay in the first place), but who have not (yet) been defined as permanently disabled; see the next section for details. This program has become very important in Norway, both because of its rapidly increasing caseloads, and because of its role as the major arena for medical and vocational rehabilitation attempts. Figure 1 illustrates the rising significance of the temporary disability insurance program, both in absolute terms and - more strikingly - relative to the unemployment insurance program. In 1992, there were more than two persons claiming unemployment insurance (UI) for each person claiming temporary disability insurance (TDI). By 2008, this pattern had been dramatically reversed, with around four TDI claimants for each UI claimant. 


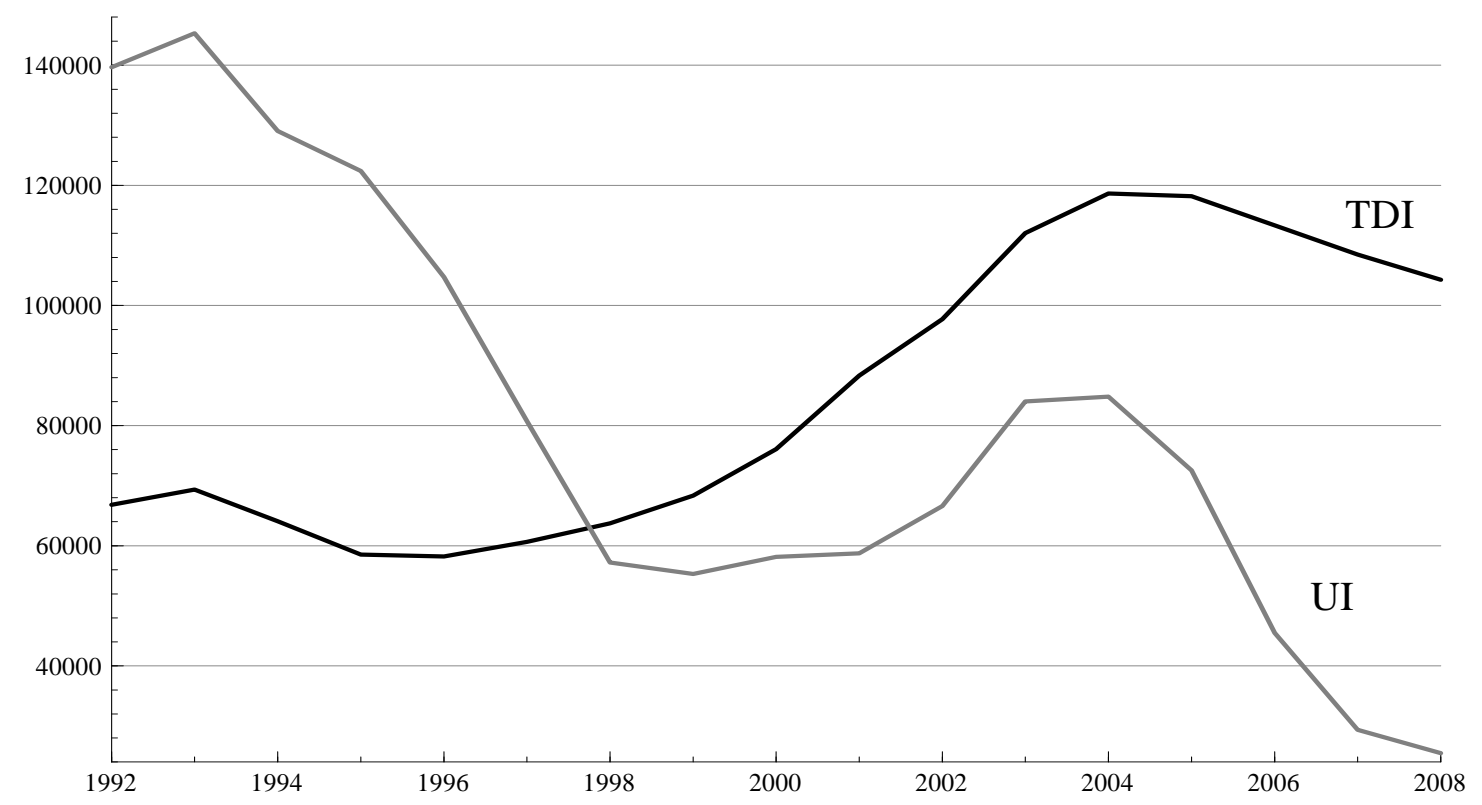

Figure 1. The numbers of temporary disability insurance (TDI) and unemployment insurance (UI) claimants in Norway 1992-2008 (annual averages of stocks registered at the end of each month).

Source: Own calculations based on administrative registers

To reliably identify the role of economic incentives, we take advantage of a social experiment in the form a full-scale overhaul of the TDI benefit scheme in January 2002. This overhaul introduced a new principle for calculation of benefits, from being based on the entire labor income path of the individual, to become based on the labor income observed in the last year (or the last three years) prior to disablement. Furthermore, the reform raised the minimum level of benefits and reduced the maximum child allowance payment. As a result, the overhaul lifted the benefit level for individuals with certain income paths and personal characteristics, and reduced benefits for others. On average, the reform implied an absolute change in individual benefit entitlements (positive or negative) of 23 percent. We use this reform to address the question of how the compensation level affects the duration and outcome of TDI spells for persons deemed to be $100 \%$ disabled at the time of entry into TDI. This is done within the framework of multivariate hazard rate models, where the (log) benefit level is the explanatory variable of interest. To ensure that this variable helps us identify the causal responses to the level of monetary compensation, we control for spurious correlations between replacement levels and indi- 
vidual resources/behaviors by conditioning the analysis on the hypothetical (log) replacement levels that the claimants would have had under both the old (pre-reform) and the new (post-reform) regimes. In addition, the analysis accounts for calendar time effects in a nonparametric fashion. Since the reform affected different claimants differently, this does not generate a perfect multicollinearity problem, but ensures that the variation in benefits used to identify causal responses is entirely reform-driven. We demonstrate the credibility of this approach through a number of robustness exercises and placeboanalyses.

The main finding of our paper is that economic incentives do matter for the duration and outcomes of temporary disability insurance spells. The elasticity of the transition rate to employment with respect to the benefit level is estimated to be -0.30 , whereas the corresponding elasticities of the transitions to permanent disability and regular unemployment are estimated to -0.34 and -0.41 , respectively. In total, a $10 \%$ increase in the benefit level implies around a $3 \%$ increase in TDI duration. Despite the huge differences in institutional setting, this is not very far from results obtained for the U.S. workers' compensation program (Butler and Worrall, 1985; Meyer et al., 1995). To put the implied labor supply responsiveness into perspective, it may be noted that for unemployment insurance (UI) claimants in Norway, the elasticity of the employment hazard with respect to the UI benefit level has previously been estimated to average around -0.65 (Røed and Zhang, 2005). TDI claimants thus seem to be less responsive to financial incentives than UI claimants. However, taking into account that the TDI claimants analyzed in this paper were declared $100 \%$ disabled at the time of entry into the program, we view the estimated responses as being of considerable magnitudes. They clearly illustrate the existence of a "common support” for unemployment and disability insurance programs. This interpretation is further bolstered by our finding that the transition rate from TDI to regular employment is significantly affected by local labor demand factors.

\section{Institutions and data}

There are basically three (normally sequential) social insurance programs providing wage replacement for persons with health problems in Norway. The first is sickness benefits for employees (sick-pay). These benefits typically provide $100 \%$ wage compensation, 
but with a maximum duration of one year. During this period, the employees are also protected against displacement on grounds related to the sickness. The second is the temporary disability insurance program, which is the program examined in the present paper. It provides benefits to employees who have exhausted their sick-pay - and in most cases no longer have a job - as well as to some individuals who were not eligible for sick-pay because they did not have a job at the time of disablement either. TDI benefits typically amount to around two thirds of previous earnings, subject to a minimum and a maximum threshold. A TDI spell consists of periods with medical and/or vocational rehabilitation. During medical rehabilitation, the claimant receives medical or psychological treatment and/or is allowed to recover through rest. During vocational rehabilitation, he/she participates in courses/education or work training intended to enhance employability. The medical rehabilitation period is in principle limited to one year, but additional periods are frequently granted. In practice, it seems that the most commonly used duration limitation for passive benefit receipt (without participating in vocational training) in the TDI program is two years. ${ }^{1}$ The third program is that of permanent (or, as explained below, semipermanent) disability insurance (PDI). These benefits also amount to around two thirds of previous earnings, and entail no further rehabilitation or activation attempts.

With the exception of a firm pay liability period during the first 16 days of sickpay spells, all three programs are fully paid for by the state and financed through general (payroll) taxation. In contrast to, e.g., the workers' compensation programs in the U.S., there is no requirement that the sickness/disability is work-related. But all claims need to be certified by a physician (except for sick-pay spells lasting only a few days).

The analyses in this paper are based on all new entries to TDI from January 1999 through December 2004. In the middle of this period (January 2002) the TDI benefit system was reformed. Before the reform, the benefits were calculated on the basis of a socalled "pension model”, implying that a claimant's compensation level was determined by a combination of the number of years with earnings above a certain threshold (up to a maximum of 40 years) and the actual income earned in the 20 best years. Potential future

\footnotetext{
${ }^{1}$ Based on inspection of the data used in this paper, we find that the probability of ending a TDI spell without any participation in activation exhibits a large spike at exactly two years duration (with more than a doubling of the benefit-termination rate), but no spike at one year duration.
} 
earnings until the ordinary retirement age of 67 years were included in this calculation, assuming a continuation of the income level earned the last 1-3 years before the disablement occurred or (if higher) during the best half of all previous years after the age of 17 . Immigrants with few years of residence in Norway were not fully compensated. For breadwinners, there were substantial means-tested allowances for children and nonworking spouses. And since the TDI benefit was considered a pension, it was subject to a lower tax rate than labor earnings.

After the reform, TDI benefits are calculated on the basis of earnings during the past calendar year or the average of the past three years (whichever is highest). The replacement ratio is 66 percent of earnings up to a ceiling of approximately NOK 500,000, which roughly corresponds to EUR 67000 (2012). ${ }^{2}$ The child allowances have been reduced by up to two thirds (but no longer means-tested), and the allowance for a nonworking spouse has been removed completely. Rather than being considered a pension, the new TDI benefit generates pension entitlements. This implies that the new benefit is subject to a higher tax rate than the old one, but at the same time makes a contribution to the individual's old age pension. The reform also implied a rise in the minimum (annual) level of TDI benefits, from around NOK 82,000 (EUR 11,000) before the reform to NOK 131,000 (EUR 17,600) after the reform. And contrary to the pre-reform regime, immigrants now only need three years of residence in Norway to receive the same compensation level as natives (and be entitled to the minimum levels).

The reform was implemented such that persons who started their TDI spell before the reform were subject to the old calculation rules throughout their spell (even if it stretched into the post-reform period), whereas persons who started afterwards were subject to the new rules. However, for persons who had an ongoing spell at the time of the reform - and who would have received higher benefits based on the new regulations - it was possible to apply for an immediate transfer to the new system.

The reform produced potential winners and losers; see Hardoy et al. (2004). Among the winners were claimants with very low or unstable past earnings and immigrants with few years of residence in Norway, particularly those without children. Among

\footnotetext{
${ }^{2}$ All amounts in this paper are inflated to 2012 value, and EURO-equivalents are computed on the basis of the exchange rate of August 2012.
} 
the losers were claimants with a recent decline in earnings and claimants with many children and/or a non-working spouse. Some claimants were more or less "sheltered" from the pecuniary impact of the reform, however. In particular, all public sector workers are covered by an occupational pension arrangement that effectively shields them from changes in the level of social security benefits. The reason for this is that the occupational pension system in the public sector prescribes the same effective replacement rate of 66 percent (of the earnings level just prior to disablement) for all employees. The social security payments are simply topped up to achieve this outcome. Hence, any change in the social security benefit is automatically offset through a counteracting change in the occupational benefit payment. For this reason, we remove the persons with a public sector occupational pension entitlement from our main sample, and use them in a "placebo analysis” instead.

\section{Definition of outcomes and descriptive statistics}

Our data consist of merged administrative registers, encrypted to prevent identification of individuals. They cover all TDI spells in Norway on a monthly basis, their starting dates and their stopping dates. By combining information from several administrative registers, we are able to compute the benefit entitlements corresponding to the pre-reform and postreform regimes (regardless of which regime each person actually belonged to) on the basis of essentially the same information as that available to the Social Security Administration (SSA). We are also able to identify the outcome of each spell in terms of the main economic activity afterwards. Finally, our data include comprehensive information about the claimants, such as gender, age, educational attainment, marital status, number and age of children, the origin country of immigrants (and years since migration), place of residence, and labor market history.

The starting point of our analysis is the set of all "new" entrants to TDI in Norway during the period from the beginning of 1999 through 2004. A new entrant in a month $t$ is defined as a person who has a recorded starting date in this month and did not receive TDI benefits in any of the last 12 months prior to month $t$. We make this rather strict definition of "newness" to ensure that we really follow individuals from the beginning of a benefit claim period. A spell is assumed to have ended in a month $t$ if the spell has a 
recorded stopping date in that month, and the person did not receive any TDI benefits the following four months $(t+1, t+2, t+3$ or $t+4)$. Shorter periods out of TDI are censored (implying that we merge spells that are less than four months apart). There are basically four (mutually exclusive) ways in which a TDI spell can end: i) with a transition to employment, ii) with a transition to the permanent disability insurance program, iii) with a transition to regular unemployment (with or without unemployment insurance eligibility), or iv) with uninsured non-participation (or to jobs that are too small to satisfy our definition of "employment”; see below). An important goal of the program is to promote transitions to employment. Claimants may apply for permanent (or semi-permanent; see below) disability benefits, however, if they still consider themselves to be unfit for regular work, normally after appropriate rehabilitation attempts have been made (or at least seriously considered). Claimants may also be declared fit for work even when they do not have any job to go to. In such cases, they may choose to register as unemployed or simply pull out of the labor force without any income support (except, possibly, social assistance).

In the main part of our statistical analysis, we will define "employment” as having labor earnings and/or business income amounting to at least 7,000 NOK per month during the 12-month-period directly following the exit. In a robustness exercise, we define it instead as having a recorded employment spell in the employer-employee-register (regardless of earnings) or a business income exceeding 7,000 NOK per month. ${ }^{3}$ In both cases, we give priority to employment transitions, implying that transitions for which we both observe employment and a social security transfer consistent with one of the other destination states, are defined as transitions to employment. The notion of "semipermanent” disability insurance arises from the introduction in 2004 of a time-limited disability pension in Norway. The idea was to create a program somewhere between the TDI and the permanent disability program (PDI), without the rehabilitation/activation ambitions embedded in TDI, but also without the permanency associated with PDI. In practice, it turned out to be a sort of waiting-room for PDI, and it was abolished in 2010.

\footnotetext{
${ }^{3}$ The reason why we do not rely on the employer-employee-register as our main strategy is that the quality of the stopping dates in these records is poor for the period covered in this analysis; hence, we worry that we then include past employment spells that were not appropriately out-registered.
} 
Consistent with this, we treat in this paper the time-limited and the time-unlimited disability benefit programs as a single permanent disability insurance state.

We limit the analysis to persons of age 27-55 who were registered as 100 percent disabled at the time of entry. The cut-off at age 27 is imposed because there are special rules applying for people who become disabled before that age due to particularly serious and objectively verifiable disabilities, and, based on our data, we are not able to identify this group. The cut-off at age 55 is imposed to stay clear of issues related to early retirement. In total, this gives us 170,129 TDI spells. However, in the causal analysis, we can only use spells for which the compensation level was potentially affected by the reform, i.e., spells not covered by a public occupational pension. This leaves us with 155,803 spells (the remaining spells are used in a placebo analysis). ${ }^{4}$ Table 1 offers some descriptive statistics for our main sample. We see no conspicuous changes in the composition of individual and background characteristics from the pre-reform to the post-reform period. Average TDI benefits rose by around $15 \%$, but as we show below, this was a result of higher benefit levels in the new system, and not of changes in the claimant composition. To ensure comparability of the pre-reform and post-reform outcome distributions, we have right-censored all spells after 48 months to compute the statistics in Table 1 (since this is the longest period we can track the last entrants into our dataset). ${ }^{5}$ We report average spell durations (with right-censored spells counting 48 months), the distribution of states immediately after exit, and the distribution of states four years after entry to TDI (regardless of whether the spell is completed or not). Average duration did not seem to change from the pre-reform to the post-reform period, but the distribution of outcomes changed in the direction of higher employment propensities. This pattern is particularly marked for the statuses recorded four year after program entry, where the employment rate rose from $40 \%$ for the pre-reform cohort to around $46 \%$ for the post-reform cohort. The fractions who after four years had moved on to the permanent disability program were roughly the same in the two cohorts, around $23-24 \%$.

\footnotetext{
${ }^{4}$ Note that the fraction of employees from the public sector entering TDI is much larger than indicated by the 13,943 observations excluded from the analysis. However, many of these employees did not have sufficient tenure (or work-hours) to qualify for a full occupational pension and were therefore affected by the reform of the TDI program.

${ }^{5}$ In the statistical analysis in the next section, we do not right-censor spells exceeding 48 months.
} 


\begin{tabular}{|c|c|c|}
\hline & $\begin{array}{l}\text { Pre-reform entrants } \\
\quad(1999-2001)\end{array}$ & $\begin{array}{l}\text { Post-reform entrants } \\
\text { (2002-2004) }\end{array}$ \\
\hline Number of new TDI entrants to $(\mathrm{N})$ & 69,218 & 86,585 \\
\hline \multicolumn{3}{|l|}{ Individual and background characteristics (at entry) } \\
\hline \multicolumn{3}{|l|}{ Demographic characteristics } \\
\hline Mean age & 40.2 & 40.3 \\
\hline Percent women & 50.2 & 51.0 \\
\hline Percent married/cohabiting & 51.8 & 50.4 \\
\hline Percent separated/divorced & 18.8 & 18.5 \\
\hline Percent with children below 18 years of age & 47.7 & 47.7 \\
\hline Immigrants & 10.2 & 12.2 \\
\hline \multicolumn{3}{|l|}{ Educational attainment (percent) } \\
\hline Compulsory school only & 42.5 & 39.6 \\
\hline Lower secondary school & 20.1 & 16.9 \\
\hline Upper secondary school & 25.7 & 29.1 \\
\hline College/University education & 10.3 & 12.3 \\
\hline Unknown & 1.4 & 2.1 \\
\hline Percent who was employed the previous year & 83.8 & 83.7 \\
\hline Average annual earnings last 3 years (NOK, 2012-value) & 314,042 & 316,194 \\
\hline Months with social insurance payments last 3 years & 16.1 & 16.6 \\
\hline Mean level of annual TDI benefits (NOK 2012 value) & 188,332 & 217,202 \\
\hline \multicolumn{3}{|l|}{ Outcomes } \\
\hline Mean duration (\# of months, right-censored at 48 months) & 24.7 & 24.6 \\
\hline \multicolumn{3}{|l|}{ Outcome of spells (percent) } \\
\hline Regular employment & 43.0 & 45.5 \\
\hline Permanent disability & 18.1 & 16.8 \\
\hline Unemployment & 1.6 & 2.0 \\
\hline Non-participation (without income support) & 17.1 & 17.4 \\
\hline Spells still in progress after 48 months & 20.4 & 18.4 \\
\hline \multicolumn{3}{|l|}{ Economic status four years after entry to TDI (percent) } \\
\hline Regular employment & 39.6 & 45.7 \\
\hline Permanent disability & 24.4 & 23.0 \\
\hline Unemployment & 1.6 & 1.0 \\
\hline Non-participation (without income support) & 10.4 & 9.7 \\
\hline Still/back in TDI & 24.1 & 20.6 \\
\hline
\end{tabular}


Note that we have no ambition of identifying the effects of the reform as such. That would be very difficult, since the implementation of the reform coincided with other developments that probably contributed to the rise in employment propensities described above. In particular, it coincided with a moderate cyclical downturn in Norway that resulted in rising unemployment during 2002 and 2003, followed by a very strong recovery (see Figure 1). Moreover, after the turn of the century, the government's policy priorities shifted markedly toward activation and more intensive use of vocational rehabilitation programs.

Since TDI benefit entitlements are determined on the basis of the claimants' own past labor market behavior, the cross-sectional variation in benefit levels is of course anything but randomly assigned. However, the 2002-reform induced a random-assignmentlike source of variation related to the exact timing of entry into the program. The key idea of the present paper is to exploit this particular source of variation to identify and estimate the causal effects of interest. It is the idiosyncratic impacts of the reform on individual benefit levels that we use to identify the behavioral responses to the level of TDI benefits. We now give a more detailed description of these impacts. Let $b_{i}^{o}$ be the (natural log of the) benefit level according to the old (pre-reform) rules and let $b_{i}^{n}$ be the benefit level according to the new (post-reform) rules (adjusted for less generous tax treatment). ${ }^{6}$ For entrants in 1999-2001, actual benefits $b_{i}^{a}$ are equal to $b_{i}^{o}$ until January 2002, after which it is equal to $b_{i}^{n}$ if $b_{i}^{n}>b_{i}^{o}$ and $b_{i}^{o}$ otherwise. For entrants in 2002-2004 $b_{i}^{a}$ is always equal to $b_{i}^{n}$. Note, however, that both benefit levels $\left(b_{i}^{n}, b_{i}^{o}\right)$ can be computed for all entrants. This implies that we can also calculate each individual's hypothetical benefit gain $g_{i}$ resulting from the reform as $g_{i}=b_{i}^{n}-b_{i}^{o}$.

\footnotetext{
${ }^{6}$ Since after-tax benefit levels are affected by potentially endogenous factors (such as the labor supply of other family members), we compute annual benefit levels before tax, but adjust the post-reform benefit levels downward by the general difference in pre- and post-reform tax rates (the difference between the tax rate on pensions and wage earnings).
} 


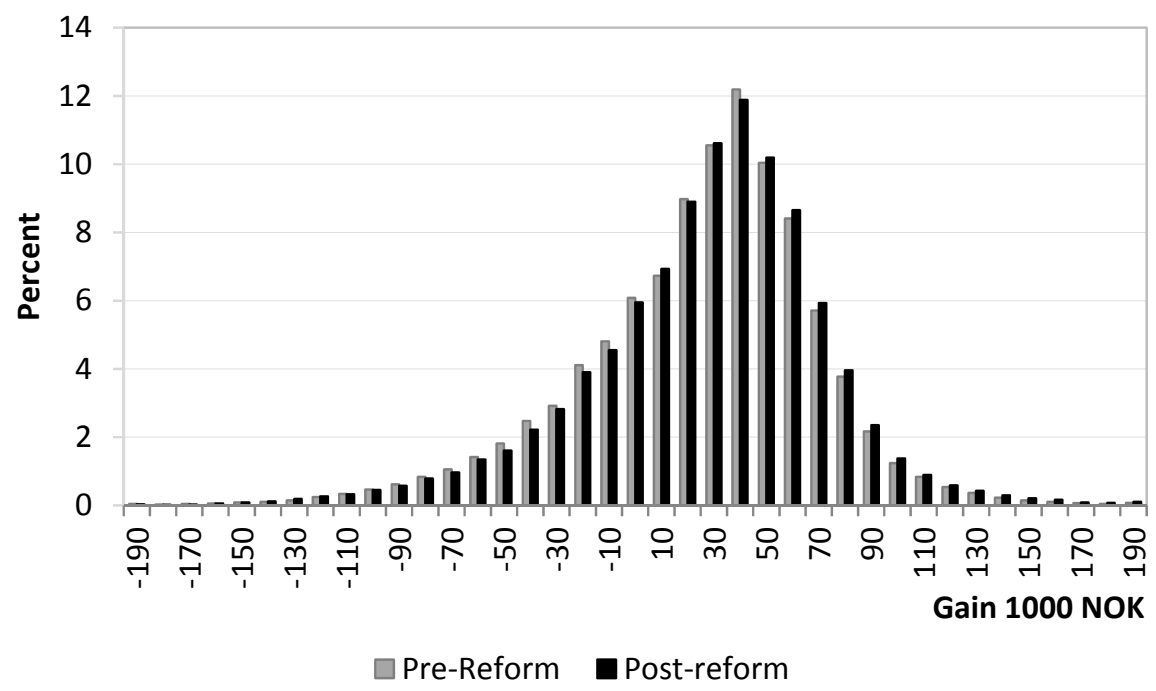

Figure 2. The distribution of gains before and after the reform

Note: Numbers on horizontal axis indicate cell-midpoints, with the range of each cell being 10,000 NOK (except at the two ends, where, e.g., 190 means > 185,000)

Figure 2 presents the distributions of the hypothetical benefit gains $g_{i}$ for TDI entrants in our main sample prior to and after the reform, respectively. There are two important points to note from this graph. The first is that the reform had a substantial impact on benefit levels. On average, the absolute (positive or negative) value of the gain $\left(\frac{1}{N} \sum_{i}\left|g_{i}\right|\right)$ was as large as 43,338 NOK (measured in 2012-value), which corresponds to 23 percent of the average pre-reform benefit level. There were more winners (76 \%) than losers, and the average gain was 26,037 NOK. The second point to note is that the gainsdistributions were quite similar before and after the reform. Although there was a slight movement toward entrants benefiting from the reform, the average gain increased by only NOK 1,878 , which is less than $1 \%$ of the average benefit level. This indicates that the reform's effect on the pattern of entries was minor. This is further illustrated in Figure 3, where we have plotted the number of entrants and their average gain-levels for each month. There was a rise in average gains during 1999 and the first half of 2000, most likely related to the overall rise in entry during this period. There were no conspicuous changes around the time of the reform in 2002. Since our empirical strategy relies on the 
reform-initiated change in benefits being exogenous as viewed from the agents' point of view, this is reassuring. ${ }^{7}$

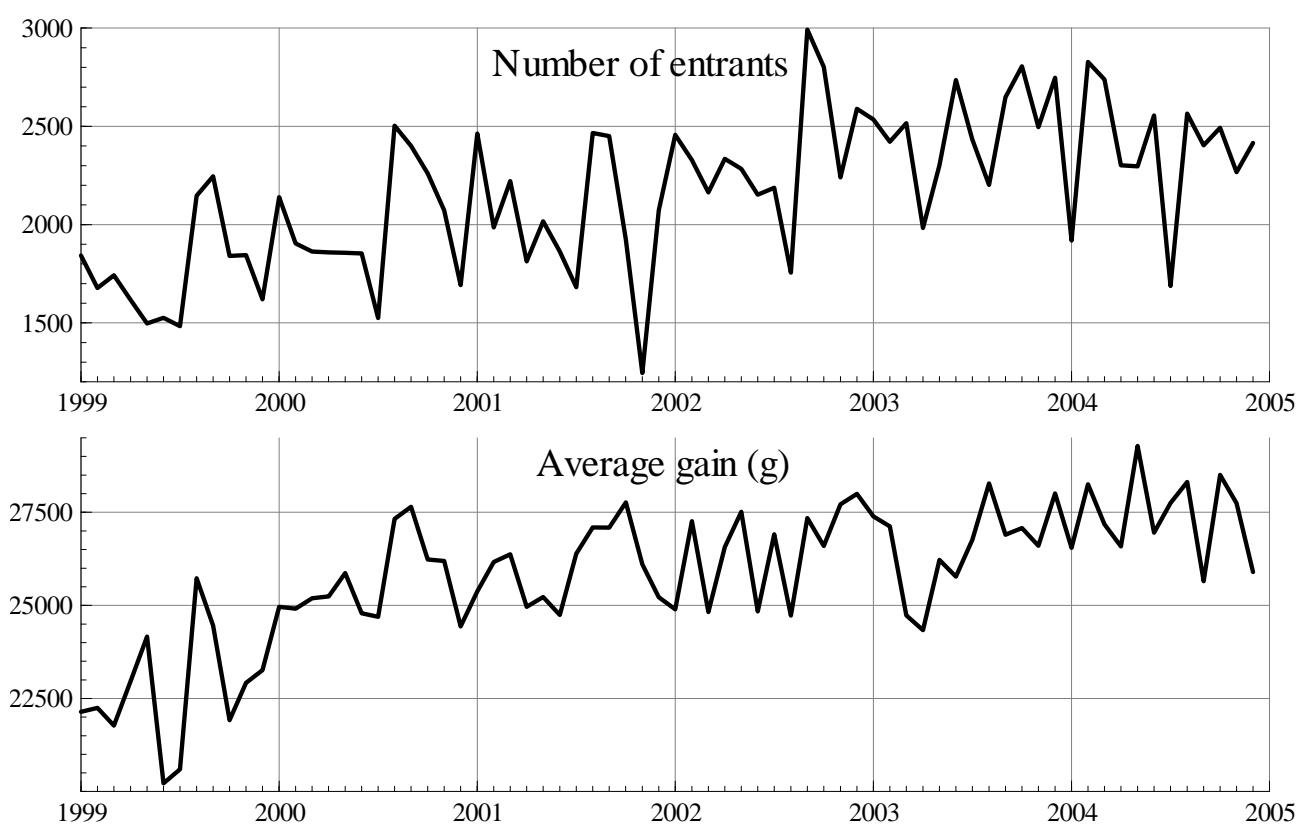

Figure 3. Number of entrants to TDI each month (upper panel) and average hypothetical gains (lower panel)

An entrant with a positive gain $g_{i}>0$ would clearly prefer the post-reform benefit regime, while a person with $g_{i}<0$ would prefer the pre-reform regime, ceteris paribus. Let $\left(\mathrm{A}_{0}, \mathrm{~A}_{1}\right)$ denote the groups with $g_{i}>0$ who entered rehabilitation before and after the reform, respectively; and let $\left(\mathrm{B}_{0}, \mathrm{~B}_{1}\right)$ denote the corresponding groups with $g_{i}<0$. Since the $\mathrm{A}$ and $\mathrm{B}$ groups were affected in opposite directions by the reform, we can use a simple descriptive difference-in-difference (DiD) methodology to obtain a rough indication of whether the reform affected behavior or not. Table 2 presents some descriptive statistics on the outcomes recorded for potential "winners" and "losers", both before and after the reform. The differences-in-differences (and the ratios-of-ratios) in mean outcomes indicate that there is a positive causal relationship between the benefit level and spell

${ }^{7}$ The upper panel of Figure 3 indicates that there was a marked drop in the number of entrants in November 2001, i.e., two months before the implementation of the reform. But since there were no corresponding changes in the gains, this does not seem to have resulted from "strategic" timing of entry. In the statistical analysis, we nevertheless perform a robustness analysis where we exclude entrants just before and just after the reform. 
duration. Spell duration increased for persons with characteristics implying higher benefits in the post reform period (the A-group) and declined for persons with characteristics implying lower benefits (the B-group). The DiD effect estimator for the effect of being a winner rather than a loser is a 1.48 month increase in TDI duration. Looking at the ratiosof-ratios (RoR) instead indicates a $6 \%$ increase (which is in line with the DiD estimator). The corresponding estimated impacts on the distribution of outcomes are small; the most important effect being that a larger fraction of the spells are not completed within 4 years.

Table 2. The relative performance of hypothetical winners and losers - before and after the reform. Entrants in 1999-2001 and 2002-2004

\begin{tabular}{lcccccc}
\hline & \multicolumn{2}{c}{$\begin{array}{c}\text { Pre-reform } \\
(1999-2001)\end{array}$} & \multicolumn{2}{c}{$\begin{array}{c}\text { Post-reform } \\
(2002-2004)\end{array}$} & $\begin{array}{c}\text { Difference in Dif- } \\
\text { ferences }\end{array}$ & Ratio of Ratios \\
\cline { 2 - 7 } & $\mathrm{A}_{0}$ & $\mathrm{~B}_{0}$ & $\mathrm{~A}_{1}$ & $\mathrm{~B}_{1}$ & $\left(\mathrm{~A}_{1}-\mathrm{B}_{1}\right)-\left(\mathrm{A}_{0}-\mathrm{B}_{0}\right)$ & $\left(\mathrm{A}_{1} / \mathrm{B}_{1}\right) /\left(\mathrm{A}_{0} / \mathrm{B}_{0}\right)$ \\
\cline { 2 - 7 } & 23.72 & 25.07 & 24.02 & 23.89 & 1.48 & 1.06 \\
Mean duration & & & & & & \\
Percent of spells end- & & & & & & \\
ing in & & & & & -0.98 & 0.97 \\
Regular employment & 45.00 & 37.04 & 47.10 & 40.13 & -0.16 & 0.99 \\
Permanent disability & 17.90 & 18.52 & 16.64 & 17.42 & -0.01 & 0.96 \\
Unemployment & 1.39 & 1.70 & 1.92 & 2.24 & -0.96 & 1.11 \\
Non-participation & 15.90 & 20.67 & 16.01 & 21.74 & 2.11 & \\
Censored & 19.82 & 22.07 & 18.33 & 18.47 & & \\
Number of spells (N) & 51,939 & 17,279 & 66,264 & 20,321 & & \\
\hline
\end{tabular}

Note: Since the last (2004) entrants to TDI can only be followed for 48 months, we have for the sake of comparability right censored all the spells at 48 months in the computation of this table.

Although the DiD-estimators indicate that there were behavioral responses to the changes in benefit levels, it is difficult to give these effects a clear quantitative interpretation, since they represent averages over a distribution of benefit changes. This is what we turn to in the next section.

\section{Empirical strategy}

To quantify the effects of marginal changes in the benefit level on the duration and outcome of TDI, we estimate a number of multivariate mixed proportional hazard (MMPH) rate models. The models are designed to exploit the random-assignment-like variation in benefit levels arising from the reform. An important element of our strategy is to use both the two hypothetical $\left(b_{i}^{n}, b_{i}^{o}\right)$ and the actual benefit levels $\left(b_{i}^{a}\right)$ as explanatory variables in the statistical analysis. The idea is that the hypothetical benefit levels then capture all the spurious effects arising from the fact that the benefit schedules depend on past behavior, 
while the determination of which of the two benefit levels the claimant actually gets is quasi-randomly assigned; i.e., it only depends on the timing of disablement. In this section, we explain in more detail how we set up our baseline model; i.e., the model used to obtain our main results. The alternative models that we estimate and discuss later on are based on exactly the same methodology, but with variations in the analysis population and in the definition of the outcome-space.

We start out with $i=1, \ldots, N$ new entrants to TDI during the period from January 1999 to December 2004. Let $k=1, \ldots, 4$, denote the set of potential events; i.e., employment $(k=1)$, permanent disability $(k=2)$, unemployment $(k=3)$, and non-participation without income support $(k=4)$. Spells that are still ongoing at the end of 2008 are rightcensored. We also right-censor spells in cases where the claimants die or migrate to another country.

As we observe labor market status by the end of each month only, we set up the statistical model in terms of grouped hazard rates. To start with, we write the integrated month-specific hazard rates $\varphi_{k i t}$ as functions of the benefit level $b_{i}^{a}$, calendar time $s_{t}$, local labor market tightness $\mathrm{LMT}_{i}$, spell duration $d_{i t}$, observed (time-varying) individual characteristics $x_{i t}$, and unobserved (time-invariant) individual characteristics $v_{k i}$; i.e.,

$$
\varphi_{k i t}=\int_{t-1}^{t} \theta_{k i s} d s=\exp \left(\delta_{k} b_{i}^{a}+\sigma_{k t} s_{t}+\gamma_{k} L M T_{i t}+\lambda_{k d} d_{i t}+\beta_{k} x_{i t}+v_{k i}\right), \quad k=1, \ldots, 4
$$

where $\theta_{\text {kis }}$ is the underlying continuous-time hazard rate, which is assumed to be constant within each month. The vector $s_{t}$ contains one indicator for each calendar time quarter in the analysis period (40 dummy variables). The local labor market tightness indicator $L M T_{i t}$ is computed separately for each of Norway's 90 travel-to-work-areas and measures for each month the (log of the) fraction of unemployed job seekers that found work. The vector $d_{i t}$ contains indicator variables denoting claimant i's spell duration measured in quarters. The vector of individual characteristics $x_{i t}$ contains the following variables: gender and family situation (10 dummy variables), nationality (2 dummy variables), educa- 
tion (5 dummy variables), age (32 dummy variables), county (19 dummy variables), and labor market tightness at the time of entry. ${ }^{8}$

The parameters of main interest are the benefit elasticities $\left(\delta_{k}\right)$. As noted above, the benefit level $b_{i}^{a}$ is computed in a way that makes it dependent on past labor market behavior and current family situation in a rather complex way; hence it is unlikely that $b_{i}^{a}$ is uncorrelated to the unobserved characteristics $v_{k i}$. However, provided that the unobserved characteristics are time-invariant, we can represent the linear dependencies between them and the actual benefit level by functions linking them to the two hypothetical benefit levels instead; i.e.,

$$
v_{k i}=\alpha_{o k} b_{i}^{o}+\alpha_{n k} b_{i}^{n}+\varepsilon_{i k}, k=1, \ldots, 4 .
$$

We then have - by construction - that $\varepsilon_{i k}$ is orthogonal to $b_{i}^{a}$. Hence, by including the two hypothetical benefit levels in Equation (1), we can obtain unbiased estimates of the benefit elasticities. The intuition is that while the benefit level calculated according to, say, the pre-reform rules can have causal effects in the pre-reform period only, its spurious effects apply to the post-reform period as well. The hazard rates used to estimate the model are consequently specified as:

$$
\varphi_{k i t}=\exp \left(\delta_{k} b_{i}^{a}+\sigma_{k t} s_{t}+\gamma_{k} L M T_{i t}+\lambda_{k d} d_{i t}+\beta_{k} x_{i t}+\alpha_{o k} b_{i}^{o}+\alpha_{n k} b_{i}^{n}+\varepsilon_{i k}\right), \quad k=1, \ldots, 4
$$

To avoid unjustified restrictions on the heterogeneity distribution, we estimate the model in a completely nonparametric fashion, implying that unobserved heterogeneity is treated as a joint discrete distribution with an unknown number of support points. Following recommendations provided by Gaure et al. (2007), we have used the Akaike Information Criterion (AIC) for model selection. The likelihood function and the algorithm used to maximize it are described in a separate Appendix.

\section{Main estimation results}

Table 3 presents the main estimation results from our baseline model. The results indicate that higher benefits significantly reduce the exit rates from TDI. The estimated benefit elasticities are -0.30 for the transition to employment, -0.34 for the transition to perma-

\footnotetext{
${ }^{8}$ Local labor market tightness at the time of TDI entry is included to account for any cyclical variation in the sorting into the program.
} 
nent disability, -0.41 for the transition to unemployment, and -0.19 for transitions to unsupported non-participation.

Table 3. Estimation results main sample (standard errors in parentheses)

\section{The actual benefit level}

Log actual benefit level (causal effect)

Local labor market tightness

Log monthly transition rate from regular unemployment to employment in travelto-work area

\begin{tabular}{cccc} 
Employment & $\begin{array}{c}\text { Permanent } \\
\text { disability }\end{array}$ & Unemployment & $\begin{array}{c}\text { Non- } \\
\text { participation }\end{array}$ \\
\hline & & & \\
$-0.295^{* * *}$ & $-0.337 * * *$ & $-0.410^{* * *}$ & $-0.194^{* * *}$ \\
$(0.043)$ & $(0.066)$ & $(0.146)$ & $(0.051)$ \\
& & & \\
$0.183^{* * *}$ & -0.005 & -0.055 & $0.140^{*}$ \\
$(0.046)$ & $(0.072)$ & $(0.237)$ & $(0.075)$ \\
& & & \\
$0.369 * * *$ & 0.039 & $-0.178^{* *}$ & $-0.317^{* * *}$ \\
$(0.025)$ & $(0.037)$ & $(0.085)$ & $(0.029)$ \\
$0.627 * * *$ & $-0.118^{* *}$ & -0.090 & $-0.894^{* * *}$ \\
$(0.038)$ & $(0.058)$ & $(0.134)$ & $(0.048)$ \\
\hline
\end{tabular}

\section{Hypothetical benefit levels}

Log benefit level pre-reform rules

$(0.058)$

$(0.134)$

$(0.048)$

Note: The number of spell-observations is 155,803. The preferred model had 7 support points in the heterogeneity distribution. ${ }^{*}(*)\left({ }^{* * *}\right)$ Statistically significant at the 10(5)(1) percent level. The estimated models include the following control variable sets: Gender and family situation (10 dummy variables), nationality (2 dummy variables), education (5 dummy variables), age (32 dummy variables), county (19 dummy variables), calendar time quarter (40 dummy variables), spell duration (13 dummy variables), and local labor market tightness at entry (1 variable)

The employment hazard is positively affected by local labor market tightness. The estimated elasticity of 0.18 implies that a $10 \%$ increase in the observed local transition rate from regular unemployment to employment implies a $1.8 \%$ increase in the transition rate from TDI to employment, ceteris paribus. Since we have included calendar time dummy variables in the model, it is only idiosyncratic regional fluctuations in labor market tightness that identify this effect; national cyclical fluctuations will be absorbed by the time dummies (together with other influences that have changed over time). Given the relatively short distances between many labor market regions in Norway, it is natural to interpret the 0.18 elasticity as a lower bound on the effect of improved employment prospects in general. The hazard to non-participation is apparently also positively affected by local labor market tightness. A probable reason for this is that our definition of nonparticipation also includes small part-time jobs (see Section 3). A closer inspection of the data reveals that $35 \%$ of the transitions to non-participation involve some employment 
(with average earnings equal to 2000 NOK (260 €) per month, conditional on positive earnings).

It is notable that higher hypothetical benefit levels (according to both the pre- and post-reform calculation rules) are associated with significantly higher exit rates, particularly to employment. This implies that if we had failed to control for these two variables - and instead used all the observed variation in the actual benefit level to identify its causal effects (conditional on the other control variables) - the estimated elasticities would have become seriously biased. More specifically, we would have estimated a benefit elasticity in the employment hazard of 0.55 (with standard error 0.02 ) instead of -0.30 ; hence we would erroneously have concluded that higher benefits resulted in a significantly higher transition rate to employment. This is not surprising, since higher benefits typically results from a stronger attachment to the labor market, and hence is associated with better employment-prospects as well.
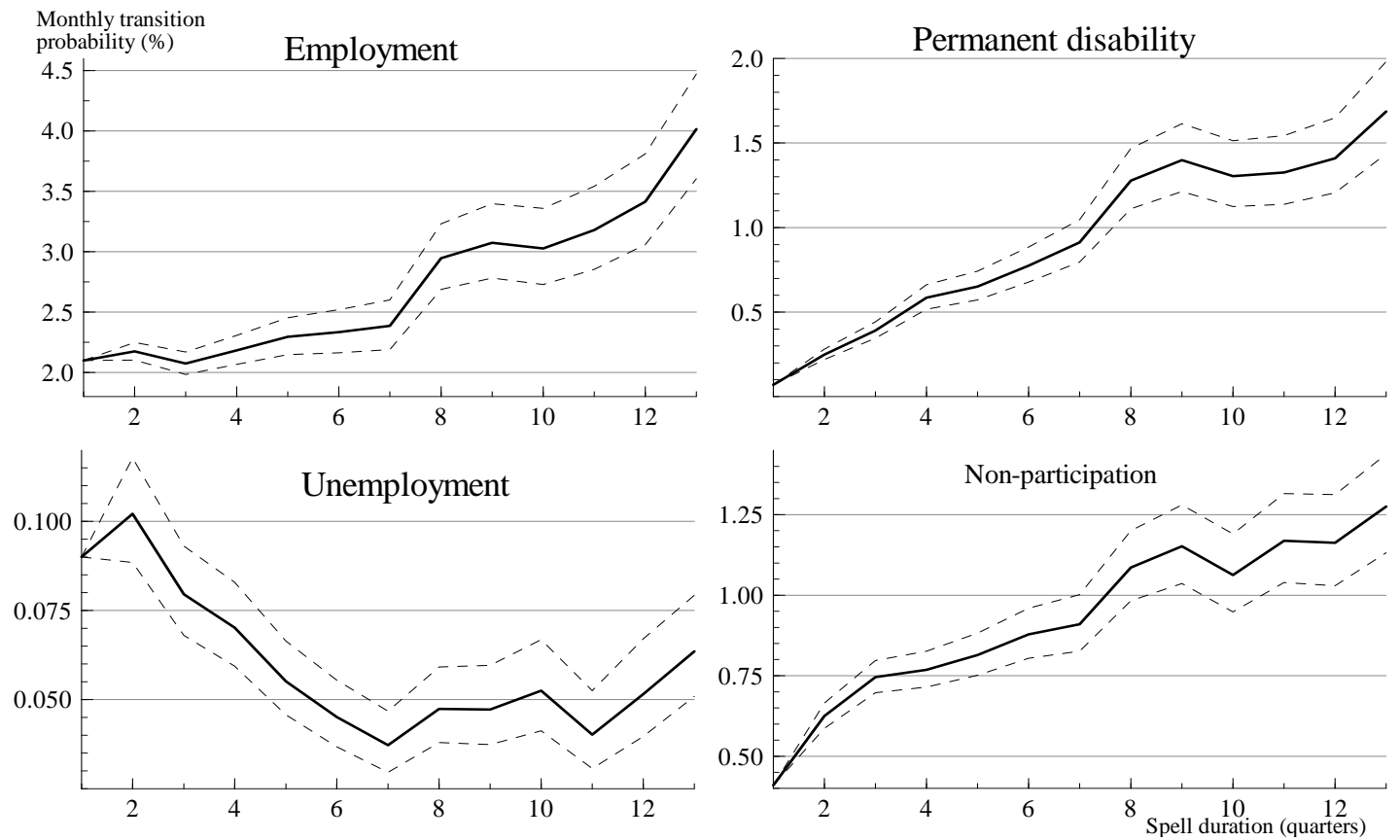

Figure 4. Estimated duration dependence profiles (with 95 percent point-wise confidence intervals)

Note: All four graphs are normalized to the average monthly transition rates observed during the first quarter after entry.

An additional assessment of the employment hazards' sensitivity with respect to economic incentives may be obtained by examining the pattern of duration dependence. 
As described in Section 2 above, TDI benefits are rarely granted for more than two years without participation in vocational rehabilitation activities. Hence, to the extent that activation requirements make TDI less attractive for some claimants with residual work capacity, we would expect the employment hazard to rise at this point, in a similar fashion to what has previously been observed for time-limited unemployment benefits (Card et al., 2007; Røed and Westlie, 2012) and sick-pay (Markussen et al., 2011). As it turns out, this is exactly what happens. Figure 4 presents the estimated duration-baselines for the four destination states. Since we have controlled (nonparameterically) for unobserved heterogeneity in this model, these profiles have a causal interpretation; i.e., they represent individual (structural) duration dependence; see, e.g., Gaure et al. (2007). We have normalized the graphs such that they portray a claimant characterized by average transition rates to all states in the beginning of the spell. While the employment hazard remains relatively stable during the first seven quarters (at a little more than $2 \%$ per month), it climbs significantly after two years, and it then rises even further after around three years. For the transitions to permanent disability and non-participation, we see a more monotonous pattern of positive duration dependence, with very low transition rates during the first few quarters. For transitions to unemployment, we see the opposite pattern, although at a persistently very low level (note the significant differences in the scales on the vertical axis across the different graphs).

It may be of some interest to see if the sensitivity to economic incentives varies across different subgroups. Table 4 presents the estimated effects of the actual benefit level for different groups, defined on the basis of gender and family situation. These results are all based on completely separate estimations for each group (using exactly the same estimation strategy as for the whole sample). Focusing on the employment hazard, we find that women are somewhat more responsive than men, that married/cohabitants are more responsive than singles, and that immigrants (from non-OECD countries) are more responsive than natives. But the main pattern is strikingly similar across the different groups, suggesting that the identified mechanisms are of fairly general nature. One particular point to note, however, is that for married claimants, the benefit elasticities are 
larger the lower is the income of the spouse. ${ }^{9}$ This may indicate that there is a liquiditycomponent in the identified responses (in addition to the moral hazard component), i.e., that claimants who are liquidity constrained and also receive low benefits are "forced" to accept sub-optimal jobs or seek alternative benefits; see Chetty (2008) for a discussion of this in relation to unemployment insurance. This mechanism may also explain the higher employment elasticity estimated for immigrants from non-OECD countries.

Table 4. Estimated effect of actual benefit level - subgroups (standard errors in parentheses)

\begin{tabular}{|c|c|c|c|c|}
\hline & Employment & $\begin{array}{c}\text { Permanent } \\
\text { disability }\end{array}$ & Unemployment & $\begin{array}{l}\text { Non- } \\
\text { participation }\end{array}$ \\
\hline Main model/sample & $\begin{array}{c}-0.295^{* * *} \\
(0.043)\end{array}$ & $\begin{array}{c}-0.337 * * * \\
(0.066)\end{array}$ & $\begin{array}{c}-0.410 * * * \\
(0.146)\end{array}$ & $\begin{array}{c}-0.194 * * * \\
(0.051)\end{array}$ \\
\hline \multicolumn{5}{|l|}{ Group specific models (main sample) } \\
\hline Men $(N=76,917)$ & $\begin{array}{c}-0.373^{* * *} \\
(0.059)\end{array}$ & $\begin{array}{c}-0.282 * * * \\
(0.085)\end{array}$ & $\begin{array}{l}-0.228 \\
(0.187)\end{array}$ & $\begin{array}{c}-0.234 * * * \\
(0.064)\end{array}$ \\
\hline Women $(\mathrm{N}=78,886)$ & $\begin{array}{c}-0.385^{* * *} \\
(0.062)\end{array}$ & $\begin{array}{c}-0.411^{* * *} \\
(0.091)\end{array}$ & $\begin{array}{c}-0.529 * * \\
(0.242)\end{array}$ & $\begin{array}{c}-0.246 * * * \\
(0.071)\end{array}$ \\
\hline Married/Cohabitants $(\mathrm{N}=86,135)$ & $\begin{array}{c}-0.422 * * * \\
(0.051)\end{array}$ & $\begin{array}{c}-0.331 * * * \\
(0.091)\end{array}$ & $\begin{array}{l}-0.412 * \\
(0.228)\end{array}$ & $\begin{array}{c}-0.205^{* * *} \\
(0.073)\end{array}$ \\
\hline $\begin{array}{l}\text { Married with low-income spouse } \\
(<\text { NOK } 330,000)\end{array}$ & $\begin{array}{c}-0.576^{* * *} \\
(0.099)\end{array}$ & $\begin{array}{c}-0.597 * * * \\
(0.144)\end{array}$ & $\begin{array}{l}-0.370 \\
(0.393)\end{array}$ & $\begin{array}{c}-0.409 * * * \\
(0.112)\end{array}$ \\
\hline $\begin{array}{l}\text { Married with medium-income } \\
\text { spouse (NOK 330,000-490,000) }\end{array}$ & $\begin{array}{c}-0.498 * * * \\
(0.115)\end{array}$ & $\begin{array}{c}-0.362 * * \\
(0.180)\end{array}$ & $\begin{array}{l}-0.796 \\
(0.542)\end{array}$ & $\begin{array}{l}-0.182 \\
(0.158)\end{array}$ \\
\hline $\begin{array}{l}\text { Married with high-income spouse } \\
\text { (>NOK 490,000) }\end{array}$ & $\begin{array}{c}-0.437 * * * \\
(0.117)\end{array}$ & $\begin{array}{c}0.129 \\
(0.173)\end{array}$ & $\begin{array}{l}-0.511 \\
(0.841)\end{array}$ & $\begin{array}{c}0.094 \\
(0.158)\end{array}$ \\
\hline Divorced $(\mathrm{N}=35,045)$ & $\begin{array}{c}-0.240 * * * \\
(0.084)\end{array}$ & $\begin{array}{c}-0.475^{* * *} \\
(0.124)\end{array}$ & $\begin{array}{l}-0.207 \\
(0.371)\end{array}$ & $\begin{array}{l}-0.223^{* *} \\
(0.100)\end{array}$ \\
\hline Never married $(\mathrm{N}=47,854)$ & $\begin{array}{c}-0.147 * * \\
(0.074)\end{array}$ & $\begin{array}{l}-0.203 \\
(0.147)\end{array}$ & $\begin{array}{l}-0.411 \\
(0.268)\end{array}$ & $\begin{array}{l}-0.125 \\
(0.105)\end{array}$ \\
\hline $\begin{array}{l}\text { Immigrants from non-OECD countries } \\
(\mathrm{N}=12,621)\end{array}$ & $\begin{array}{l}-0.502^{* * *} \\
(0.106)\end{array}$ & $\begin{array}{l}-0.111 \\
(0.154)\end{array}$ & $\begin{array}{l}-0.438 \\
(0.334)\end{array}$ & $\begin{array}{l}-0.195^{*} \\
(0.111)\end{array}$ \\
\hline
\end{tabular}

Partially disabled (alternative sample)

Less than $100 \%$ disabled at the time of

$$
\begin{array}{cc}
-0.378 * * * & -0.305 \\
(0.072) & (0.221)
\end{array}
$$$$
-0.710 * * *^{\#}
$$

$(0.236)$

Note: The variables included in these models are the same as those reported for Table 3. *(**)(***) Statistically significant at the 10(5)(1) percent level.

\# Due to the low number of observations/transitions, we were not able to estimate separate hazards for unemployment and non-participation transitions for this model; hence, the reported numbers refer to the joint destination state of unemployment/non-participation.

\footnotetext{
${ }^{9}$ It is probable that the labor supply of the spouse responds to the reduced household income caused by temporary disability; see, e.g., Hardoy and Schøne (2012). To avoid this element of reverse causation, we base the grouping in Table 4 on the income of the spouse the year before entry into TDI.
} 
As explained above, we have in our main sample only included persons who were classified as $100 \%$ disabled at the time of entry into the program. However, we have also estimated the model on entrants who were classified as partially disabled at this point (less than $100 \%$ ). Most of these claimants probably had a job at the time of entry, but had exhausted their sick pay entitlements and were still not able to take up their regular duties. The estimation results indicate that the labor supply response is even stronger for this group; see the bottom of Table 4 .

\section{Robustness and reliability}

Can we be sure that the benefit elasticities estimated in this paper really represent causality? We see two potential sources of bias: The first is selected inflows, i.e., changes in the pattern of inflows to TDI directly caused by the changes in the benefit schedule. This could violate the assumption embedded in Equation (2) that there is a stable correlation between unobserved heterogeneity and the hypothetical benefit levels. The second is biased time developments; i.e., changes in the economic environment (apart from the benefit level) that has affected persons with different benefit gains systematically differently. In addition, we have - as explained above - made a number of potentially questionable modeling choices that may have influenced the results, e.g., related to the definition of employment and the treatment of spells that were ongoing at the time of the reform.

This section evaluates robustness and reliability of our findings, focusing exclusively on the elasticities of the hazard rates with respect to the actual benefit level. Estimates are shown in Table 5, where each row represents a separate model. We first recall that the descriptive statistics presented in Section 3 did not indicate any changes in the TDI inflow patterns in response to the reform; the distributions of gains $\left(b_{i}^{n}-b_{i}^{o}\right)$ were largely the same for entrants in the pre-reform and post-reform periods. Hence, there is no a priori reason to suspect any bias caused by selected inflows. The stability in parameter estimates across sub-groups (Table 4) is also reassuring in this regard. We nevertheless check for possible "deviations" around the time of the reform by re-estimating the model with all spells starting from 6 months before to 6 months after the reform excluded from the analysis. As can be seen from Table 5, this hardly changes the estimated employment elasticity at all. The two other estimates change slightly. 
We also see no particular reason to suspect the existence of trends in the economic environment that correlate systematically with the individual factors determining benefit gains/losses. To verify this, we run three "placebo" analyses. The first is simply a reestimation of the main model on the sample of persons who were protected from the impacts of the reform because they were eligible for a public occupational pension (see Section 2). Given the low number of observations, the standard errors are too large to draw firm conclusions. But the point estimates are positive - i.e., the opposite of what we find for those who were affected by the reform - and all of them are statistically insignificant. The two other placebo-analyses are constructed by imposing false reforms in the middle of the pre-reform and the post-reform three-year periods; i.e. we estimate the models as if the reform occurred at these times. ${ }^{10}$ Again, the results tend to indicate that there were no biased trends, confirming the causal interpretation of the effects identified in our main model.

Finally, we assess robustness with respect to some potentially questionable modeling choices, also shown in Table 5. First, we drop the incorporation of unobserved heterogeneity into the model to see whether the strategy we have used to control for unobserved heterogeneity is important for our results. As it turns out, however, this has virtually no impact on any of the estimated effects. Second, we drop the imposition of the transitional rules applying for spells that were ongoing at the time of the reform (January 2002); i.e., instead of assuming that those with higher benefits in the new system switched immediately, we assume that they continued with their "old" benefit level. This reduces the estimated employment elasticity, which is consistent with a presumption that those entitled to higher benefits in the new system actually did switch. And third, we reestimate the competing risks model with an alternative definition of employment, based on records in the employer-employee-register rather than on recorded earnings (see above). This change has virtually no impact on the estimated employment elasticity.

\footnotetext{
${ }^{10}$ We right-censor all spells at the end of the three-year periods to maintain the symmetry embedded in the main model, and also to prevent the spells from being affected by the genuine reform.
} 
Table 5. Estimated effect of actual benefit level - alternative models(standard errors in parentheses)

\begin{tabular}{|c|c|c|c|c|}
\hline & Employment & $\begin{array}{c}\text { Permanent } \\
\text { disability }\end{array}$ & $\begin{array}{c}\text { Un- } \\
\text { employment }\end{array}$ & $\begin{array}{c}\text { Non- } \\
\text { participation }\end{array}$ \\
\hline Main model/sample (from Table 4) & $\begin{array}{l}-0.295^{* * *} \\
(0.043)\end{array}$ & $\begin{array}{c}-0.337 * * * \\
(0.066)\end{array}$ & $\begin{array}{l}-0.410^{* * *} \\
(0.146)\end{array}$ & $\begin{array}{l}-0.194^{* * *} \\
(0.051)\end{array}$ \\
\hline \multicolumn{5}{|l|}{ Reduced sample } \\
\hline $\begin{array}{l}\text { Excluding spells that starts from } 6 \text { months } \\
\text { before to six months after the reform } \\
(n=135,843)\end{array}$ & $\begin{array}{l}-0.302 * * * \\
(0.037)\end{array}$ & $\begin{array}{c}-0.306 * * * \\
(0.065)\end{array}$ & $\begin{array}{l}-0.378^{* *} \\
(0.154)\end{array}$ & $\begin{array}{c}-0.185^{* * *} \\
(0.049)\end{array}$ \\
\hline \multicolumn{5}{|l|}{ “Placebo" models } \\
\hline $\begin{array}{l}\text { Persons with occupational pension public } \\
\text { sector }(\mathrm{N}=14,326)\end{array}$ & $\begin{array}{c}0.179 \\
(0.168)\end{array}$ & $\begin{array}{c}0.238 \\
(0.261)\end{array}$ & \multicolumn{2}{|c|}{$\begin{array}{l}0.387^{\#} \\
(0.371)\end{array}$} \\
\hline $\begin{array}{l}\text { Erroneously placed reform in pre-reform } \\
\text { period }(N=69,218)\end{array}$ & $\begin{array}{l}-0.047 \\
(0.071)\end{array}$ & $\begin{array}{l}-0.094 \\
(0.139)\end{array}$ & $\begin{array}{c}0.145 \\
(0.272)\end{array}$ & $\begin{array}{c}0.141 \\
(0.095)\end{array}$ \\
\hline $\begin{array}{l}\text { Erroneously placed reform in post-reform } \\
\text { period }(\mathrm{N}=86,585)\end{array}$ & $\begin{array}{l}-0.021 \\
(0.075)\end{array}$ & $\begin{array}{c}-0.229 \\
(0.146)\end{array}$ & $\begin{array}{c}0.098 \\
(0.240)\end{array}$ & $\begin{array}{c}0.028 \\
(0.083)\end{array}$ \\
\hline \multicolumn{5}{|l|}{ Alternative modeling assumptions } \\
\hline Without unobserved heterogeneity & $\begin{array}{c}-0.279 * * * \\
(0.035)\end{array}$ & $\begin{array}{c}-0.312^{* * *} \\
(0.051)\end{array}$ & $\begin{array}{c}-0.411^{* * *} \\
(0.144)\end{array}$ & $\begin{array}{c}-0.224^{* * *} \\
(0.044)\end{array}$ \\
\hline Without imposing transition rules & $\begin{array}{c}-0.263^{* * *} \\
(0.036)\end{array}$ & $\begin{array}{c}-0.350 * * * \\
(0.056)\end{array}$ & $\begin{array}{c}-0.249 * \\
(0.128)\end{array}$ & $\begin{array}{c}-0.234 * * * \\
(0.044)\end{array}$ \\
\hline With alternative job definition & $\begin{array}{c}-0.312 * * * \\
(0.050)\end{array}$ & $\begin{array}{c}-0.302 * * * \\
(0.066)\end{array}$ & $\begin{array}{c}-0.516 * * * \\
(0.130)\end{array}$ & $\begin{array}{c}-0.177 * * * \\
(0.045)\end{array}$ \\
\hline
\end{tabular}

Note: The variables included in these models are the same as those reported for Table 3. *(**)(***) Statistically significant at the 10(5)(1) percent level.

\# Due to the low number of observations/transitions, we were not able to estimate separate hazards for unemployment and non-participation transitions for this model; hence, the reported numbers refer to the joint destination state of unemployment/non-participation.

\section{Long-term outcomes}

Even though the evidence presented so far indicates that economic incentives significantly affect the transition rate from temporary disability to employment and permanent disability, one may question whether these effects capture the elasticity of the timing of transitions only, or whether they persist over a longer time horizon. To investigate this issue, we have redefined the destination states so that they no longer describe the economic status observed immediately after the end of the TDI spell, but rather the status observed three years after the transition occurred. Note that we do not change any of the TDIdurations as a result of this redefinition, only the interpretation of destination states. For example, a person who made a transition from TDI to, say, inactivity, but then shows up 
as employed three years later, would in this case contribute to the analysis with an employment-transition. As it turns out, some of the claimants had returned to TDI at these later stages; hence we estimate a five-state competing risks model in this exercise where the fifth destination state is "being back in TDI". The results are presented in Table 6 . They indicate that the long-term effect on the employment propensity is even larger than the short-term effect, with the employment elasticity climbing from -0.30 for immediate job transitions to as much as -0.42 for transitions that end up in employment four years after. A similar pattern is revealed for transitions that end up in unemployment. For transitions to permanent disability and non-participation, however, there are only minor changes in the estimated benefit elasticities, and it is notable that the benefit level has no effect on the probability of returning to TDI.

Table 6. Estimated effect on transitions to outcomes measured 2-4 years after completed spells (standard errors in parentheses)

\begin{tabular}{lccccc}
\hline & Employment & $\begin{array}{c}\text { Permanent } \\
\text { disability }\end{array}$ & $\begin{array}{c}\text { Un- } \\
\text { employment }\end{array}$ & $\begin{array}{c}\text { Non- } \\
\text { participation }\end{array}$ & $\begin{array}{c}\text { Back to } \\
\text { TDI }\end{array}$ \\
\cline { 2 - 6 } Two years after exit & $-0.337 * * *$ & $-0.330 * * *$ & $-0.855^{* * *}$ & $-0.282^{* * *}$ & 0.112 \\
& $(0.046)$ & $(0.054)$ & $(0.175)$ & $(0.067)$ & $(0.091)$ \\
Three years after exit & $-0.395 * * *$ & $-0.289 * * *$ & $-0.346 *$ & $-0.271^{* * *}$ & 0.005 \\
& $(0.046)$ & $(0.051)$ & $(0.178)$ & $(0.066)$ & $(0.081)$ \\
Four years after exit & $-0.420 * * *$ & $-0.324 * * *$ & $-0.607 * * *$ & $-0.273^{* * *}$ & -0.025 \\
& $(0.049)$ & $(0.048)$ & $(0.217)$ & $(0.066)$ & $(0.084)$ \\
\hline
\end{tabular}

Note: The variables included in these models are the same as those reported for Table 3. *(**)(***) Statistically significant at the 10(5)(1) percent level.

\section{Conclusion}

Based on Norwegian administrative registers, we have utilized a large "social experiment” - consisting of a complete overhaul of the temporary disability insurance (TDI) system - to estimate the impacts of economic incentives on the duration and outcome of TDI spells. Our conclusion is that a 10 percent cut in the benefit level induces approximately a $3 \%$ increase in the hazard rate to regular employment, a $3.4 \%$ increase in the hazard rate to permanent disability, and a $4.1 \%$ increase in the hazard rate to regular unemployment (the latter from a very low level). The employment elasticity is smaller than what has previously been estimated for unemployed job seekers in Norway, indicating that temporary disabled persons indeed face a more restricted labor market choice set 
than ordinary unemployed. Given that the persons included in our analyses were considered to be $100 \%$ disabled at the time of entry to the program, we nevertheless consider the identified responses to be substantial. In addition, we have shown that the transition rate from temporary disability to employment is sensitive with respect to labor market conditions. An increase in local labor demand corresponding to a $10 \%$ increase in the transition intensity from unemployment to employment yields approximately a $1.8 \%$ increase in the transition intensity from temporary disability to employment.

Taken together, our results support the view that there is a significant labor supply potential among temporary disabled persons, and that the realization of this potential to some extent can be encourage by means of financial incentives. Yet, given the availability and generosity of alternative social insurance programs - in particular that of permanent disability - a thriftier temporary disability insurance program runs the risk of shifting parts of the caseload to other programs from which it may be even more difficult to return to employment.

\section{Appendix}

In this section, we derive the likelihood function for the model estimated in this paper. Let

$$
w_{k i t}=\delta_{k} b_{i}^{a}+\sigma_{k t} s_{i t}+\gamma_{k} L M T_{i t}+\lambda_{k d} d_{i t}+\beta_{k} x_{i t}+\alpha_{o k} b_{i}^{o}+\alpha_{n k} b_{i}^{n}, \quad k=1,2,4,
$$

where $\left(\sigma_{k t}, \lambda_{k d}, \delta_{k}, \alpha_{o k}, \alpha_{n k}, \beta_{k}\right)$ are the parameters to be recovered from the data.

The probability that individual $i$ makes a transition to state $k$ during period $t$ is equal to:

$$
p_{k i}\left(w_{k i t}, \varepsilon_{i}\right)=\left(1-\exp \left(-\sum_{k} \exp \left(w_{k i t}+\varepsilon_{k i}\right)\right)\right) \frac{\exp \left(w_{k i t}+\varepsilon_{k i}\right)}{\sum_{k} \exp \left(w_{k i t}+\varepsilon_{k i}\right)}, \varepsilon_{i}=\left(\varepsilon_{1 i}, \varepsilon_{2 i}, \varepsilon_{3 i}, \varepsilon_{4 i}\right),
$$

see Røed and Westlie (2012).

Let $o_{k i t}$ be an outcome indicator variable, which is equal to 1 if the corresponding observation ended in a transition to state $k$, and zero otherwise, and let $O_{i}$ be the complete set of outcome indicators available for individual $i$ (all periods at which individual $i$ has been at risk of making a transition of some sort). The contribution to the likelihood func- 
tion formed by a particular claimant, conditional on the vector of unobserved variables $\varepsilon_{i}$ can then be formulated as:

$$
L_{i}\left(\varepsilon_{i}\right)=\prod_{o_{k i t} \in O_{i}}\left[\begin{array}{l}
\left.\prod_{k}\left[\left(1-\exp \left(-\sum_{k} \exp \left(w_{k i t}+\varepsilon_{k i}\right)\right)\right) \frac{\exp \left(w_{k i t}+\varepsilon_{k i}\right)}{\sum_{k} \exp \left(w_{k i t}+\varepsilon_{k i}\right)}\right]^{o_{k i t}}\right] \\
\times\left[\exp \left(-\sum_{k} \exp \left(w_{k i t}+\varepsilon_{k i}\right)\right)\right]^{\left(1-\sum_{k} o_{k i t}\right)}
\end{array}\right] .
$$

In order to arrive at the marginal likelihood, we need to integrate unobserved heterogeneity $v_{i}$ out of Equation (6). We do this nonparametrically, to make sure that the results are really driven by the data and not by unjustified restrictions. In practice, this implies that the vectors of unobserved attributes are discretely distributed (Lindsay, 1983) with the number of mass-points chosen by adding points until it is no longer possible to increase the likelihood function (Heckman and Singer, 1984). Let $Q$ be the (a priori unknown) number of support points in this distribution and let $\left\{\varepsilon_{l}, q_{l}\right\}, l=1,2, \ldots Q$, be the associated location vectors and probabilities. In terms of observed variables, the likelihood function is then given as

$$
L=\prod_{i=1}^{N} \sum_{l=1}^{Q} q_{l} L_{i}\left(\varepsilon_{l}\right), \quad \sum_{l=1}^{Q} q_{l}=1 .
$$

The algorithm we use starts out estimating a null-model without unobserved heterogeneity $(\mathrm{Q}=1)$, and then expands the model step by step with one additional support point in each round. Each time, we identify a candidate for a new support point by assigning a new point with probability zero and select its location vector such that the derivative in the direction of positive probability is positive. For this we use a simulated annealing approach. We then maximize in three steps; first with respect to the probabilities, then with respect to the entire heterogeneity distribution, and finally with respect to all parameters in the model simultaneously. For the maximizations we use a combination of 
BFGS, a Newton method with line-search, and a trust-region method. Standard errors are lifted from the diagonal of the inverse of the (negative) Fisher matrix.

\section{References}

Abbring, J. H. and Van den Berg, G. J. (2003) The Nonparametric Identification of Treatment Effects in Duration Models. Econometrica, Vol. 71, 1491-1517.

Autor, D. and Duggan, M. G. (2003) The Rise in the Disability Rolls and the Decline in Unemployment. The Quarterly Journal of Economics, Vol. 118, 157-205.

Autor D., Duggan, M., and Gruber J. (2012) Moral Hazard and Claims Deterrence in Private Disability Insurance. NBER Working Paper No. 18172.

Black, D., Daniel, K., and Sanders, S. (2002) The Impact of Economic Conditions on Participation in Disability Programs: Evidence from the Coal Boom and Bust. American Economic Review, Vol. 92, 27-50.

Bratsberg, B., Fevang, E., and Røed, K. (2010) Disability in the Welfare State: An Unemployment Problem in Disguise? IZA Discussion Paper No. 4897.

Burkhauser, R. V. and Daly, M. C. (2011) The Declining Work and Welfare of People with Disabilities: What Went Wrong and a Strategy for Change. AEI Press, Washington D.C.

Butler, R. J., and Worral, J. D. (1985), Work Injury Compensation and the Duration of Non-work Spells, Economic Journal, Vol. 95, 714-724.

Card, D., Chetty, R. and Weber, A. (2007) The Spike at Benefit Exhaustion: Leaving the Unemployment System or Starting a New Job? American Economic Review, Vol. 97, No. 2 (PAP), 113-118.

Chetty, R. (2008) Moral Hazard versus Liquidity and Optimal Unemployment Insurance. Journal of Political Economy, Vol. 116, No. 2, 173-234.

Duggan, M. and Imberman, S. (2006) Why Are Disability Rolls Skyrocketing? In D. Cutler and D. Wise (eds.): Health in Older Ages: The Causes and Consequences of Declining Disability among the Elderly. University of Chicago Press.

Fredriksson, P. and Holmlund, B. (2006) Improving Incentives in Unemployment Insurance: A Review of Recent Research. Journal of Economic Surveys, Vol. 20, 357- 
86.

French, E. and Song, J. (2009) The Effect of Disability Insurance Receipt on Labor Supply. Working Paper, Federal reserve Bank of Chicago.

Gaure, S., Røed, K., and Zhang, T. (2007) Time and Causality: A Monte Carlo Assessment of the Timing-of-Events Approach. Journal of Econometrics, Vol. 141, 1159-1195.

Hardoy, I., and Schøne, P. (2012) Displacement and Household Adaption: Insured by the Spouse or the State? Mimeo, Institute for Social Research, Oslo.

Hardoy, I., Storvik, Aa., and Torp, H. (2004) Hvem år mer og hvem får mindre? Effekter av nye berekningsregler for stønader til livsopphold under attføring og rehabilitering. Rapport 2004:14, Institutt for samfunnsforskning.

Heckman, J. and Singer, B. (1984) A Method for Minimizing the Impact of Distributional Assumptions in Econometric Models for Duration Data. Econometrica, Vol. 52, 271-320.

Henrekson, M. and Persson M. (2004) The Effects on Sick Leave of Changes in the Sickness Insurance System. Journal of Labor economics, Vol. 22, 87-114.

Johansson P. and Palme, M. (2002) Assessing the Effects of a Compulsory Sickness Insurance on Worker Absenteeism. Journal of Human Resources, Vol. 37, No. 2, 381-409.

Kostøl, A. R., and Mogstad, M. (2012) How Financial Incentives Induce Disability Insurance Recipients to Return to Work. IZA Discussion Paper No. 6702.

Krueger, A. B. and Meyer, B. D. (2002) Labor Supply Effects of Social Insurance. In Auerbach, A. J. and Feldstein, M. (eds.) Handbook of Public Economics, Vol. 4. Elsevier Science, North-Holland, 2002; 2327-92.

Lindsay, B. G. (1983) The Geometry of Mixture Likelihoods: A General Theory. The Annals of Statistics, Vol. 11, 86-94.

Maestas, N., Mullen, K. and Strand, A. (2011) Does Disability Insurance Receipt Discourage Work? Using Examiner Assignments to Estimate Causal Effects of SSDI Receipt. Rand Working Paper, WR-853-2.

Markussen, S., Røed, K., Røgeberg, O., and Gaure, S. (2011) The Anatomy of Absenteeism. Journal of Health Economics, Vol. 30, No. 2, 277-292. 
Meyer, B. D., Viscusi, W. K. and Durbin, D. (1995) Workers' Compensation and Injury Duration: Evidence from a Natural Experiment, American Economic Review, Vol. 85, 322-340.

OECD (2010) Sickness, Disability and Work: Breaking the Barriers - A Synthesis of Findings across OECD Countries, OECD, Paris.

Rege, M., Telle, K., and Votruba, M. (2009) The Effect of Plant Downsizing on Disability Pension Utilization. Journal of the European Economic Association, Vol. 7, No. 5, 754-785.

Røed K. (2012) Active Social Insurance. IZA Journal of Labor Policy, Vol. 1:8 (doi:10.1186/2193-9004-1-8)..

Røed, K., Jensen, P., and Thoursie, A. (2008) Unemployment Duration and Unemployment Insurance - A Comparative Analysis Based on Scandinavian Micro Data. Oxford Economic Papers, Vol. 60, No. 2, 254-274.

Røed, K. and Westlie, L. (2012) Unemployment Insurance in Welfare States: The Impacts of Soft Duration Constraints. Journal of the European Economic Association, Vol. 10, No. 3, 518-554.

Røed, K. and Zhang, T. (2003) Does Unemployment Compensation Affect Unemployment Duration? Economic Journal, Vol. 113 (2003), 190-206.

Røed, K. and Zhang, T. (2005) Unemployment duration and economic incentives - A quasi random-assignment approach. European Economic Review , Vol. 49, 17991825.

Von Wachter, T., Song, J., and Manchester, J. (2011) Trends in Employment and Earnings of Allowed and Rejected Applicants to the Social Security Disability Insurance Program. American Economic Review, Vol. 101, No. 7, 3308-3329. 